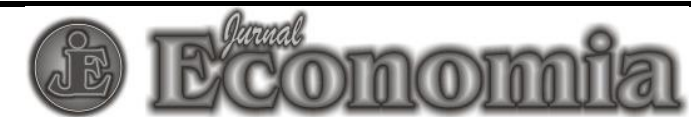

Volume 11, Nomor 2, Oktober 2015 | ISSN: 1858-2648

\section{UCAPAN TERIMA KASIH KEPADA MITRA BEBESTARI}

Dengan hormat,

Sehubungan dengan sudah terbitnya Jurnal Economia (JE) Volume 11 tahun 2015, kami segenap Dewan Redaksi mengucapkan terima kasih atas bantuan Bapak/Ibu yang telah bersedia menjadi mitra bebestari yang telah menyampaikan sumbangan pemikiran dalam melakukan pembenahan dan penyempurnaan naskah yang masuk pada dewan redaksi. Terima kasih dan penghargaan setinggi-tingginya kami sampaikan kepada:

1. Prof. Dr. I Made Narsa, M.Si.Ak. (Universitas Airlangga Surabaya, Indonesia).

2. Prof. Dr. Sucihatiningsih Dian Wisika Prajanti, M.Si. (Universitas Negeri Semarang, Indonesia).

3. Prof. Sukirno, Ph.D. (Universitas Negeri Yogyakarta, Indonesia)

4. Setyabudi Indartono (Universitas Negeri Yogyakarta, Indonesia)

5. Losina Purnastuti (Universitas Negeri Yogyakarta, Indonesia)

6. Dr. Akhmad Syakir Kurnia, M.Si. (Universitas Diponegoro Semarang, Indonesia).

7. Sukidjo (Universitas Negeri Yogyakarta, Indonesia)

8. Dr. Kurjono, M.Pd. (Universitas Pendidikan Indonesia)

9. Ali Muhson (Universitas Negeri Yogyakarta, Indonesia)

10. Nurhadi (Universitas Negeri Yogyakarta, Indonesia)

11. Mahendra Adhi Nugroho (Universitas Negeri Yogyakarta, Indonesia)

12. Bambang Suprayitno (Universitas Negeri Yogyakarta, Indonesia).

13. Muniya Alteza (Universitas Negeri Yogyakarta, Indonesia).

14. Abdullah Taman (Universitas Negeri Yogyakarta, Indonesia).

15. Ngadirin Setyawan (Universitas Negeri Yogyakarta, Indonesia).

16. Supriyanto (Universitas Negeri Yogyakarta, Indonesia).

17. Isroah (Universitas Negeri Yogyakarta, Indonesia). 


\section{INDEKS SUBJEK}

Abnormal return, 13, 14, 15

Budaya wirausaha, 89, 103, 104

Co-management, 29, 40, 41, 46

Daerah Transmigrasi, 72, 75

Daya saing, 89, 96, 103

Dividen, 200, 201, 205, 206, 207, 208, 209

Ekonomi kreatif, 153, 154, 156

Ekonomi masyarakat pesisir, 28

Entrepreneurship. Nilai, 16

Gaya kepemimpinan, 161, 162, 167

Informasi, 136, 138, 142, 183, 201, 209

Intensitas modal, 143, 148

Kepuasan kerja, 121, 122, 129, 162, 167, 168

Kinerja karyawan, 121

Komitmen organisasional, 120, 122, 129

Kompensasi, 118, 120, 122, 123, 125, 126, 128, $129,177,179,183,184$

Kompetensi, 21, 118, 120, 122, 123, 125, 127, 128, 129, 131

Komunikasi organisasi, 180, 182, 183

Kreativitas, 18

KTM, 72, 73, 74, 75, 76, 79, 80, 82, 84, 86, 88

Laba, 132, 137, 138, 143, 146, 147

Laba bersih, 137, 138
Leverage, 143, 144, 146, 148, 149

Likuiditas, 10, 13, 15, 141, 142

Mahasiswa, 7, 25, 56, 159, 172, 176

MEA, 89, 109, 150, 155, 157, 158, 159

Niat membeli, 171

Organizational citizenship behavior, 168

OVOP, $72,74,75,76,77,78,79,80,81,82,83,84$, $85,86,88$

Pemecahan saham, 10, 11, 132, 133, 135

Pendidikan ekonomi, 20, 22

Pensiun, 186, 188, 194, 195, 198, 199

Pertumbuhan laba bersih, 137, 138

Pertumbuhan penjualan, 143, 145

Perubahan sosial, 108

Prinsip 6C, 56, 59

Profitabilitas, 143, 144, 146, 149, 209

Semangat kerja, 177, 182

Sikap, 18, 20, 40, 109, 171, 175

Sosial, 31, 88, 164, 191

Split factor signal, 138

Stock split, 11, 142

Values, 16

Wirausaha, 1, 2, 3, 4, 56, 58, 84, 89 
INDEKS PENGARANG

Adhe Raka Setiawan, 200

Agus Prianto, 89

Arif Unwanullah, 107

Arum Darmawati, 143

Asri Laksmi Riani, 161

Bandi, 200

Dwi Agung Nugroho Arianto, 177

Henny Sri Astuty, 56

Lina Nur Hidayati, 143

Maghfiroh, 169

Muniya Alteza, 132

Musaroh, 132

Naning Margasari, 132
Nuraini Asriati, 72

Peter Garlans Sina, 186

Pudjo Suharso, 47

Sukidin, 47

Susilaningsih, 1

Wahyu Rusdiyanto, 161

Waspodo Tjipto Subroto, 16

Wening Asriningsih, 10

Winarno, 143

Witarsa, 26

Yudi Supiyanto, 118

Zumrottus Sa'adah, 150 


\section{PEDOMAN PENULISAN ARTIKEL JURNAL ECONOMIA}

\section{Ketentuan Umum:}

1. Artikel berupa hasil pemikiran, analisis ilmiah, kajian teori, atau hasil penelitian dalam bidang ekonomi.

2. Artikel yang dikirim ke jurnal tidak sedang dikirimkan ke jurnal/terbitan lain dan belum dipublikasikan dalam jurnal/terbitan lain.

3. Artikel dikirim dalam bentuk hardcopy dan atau softcopy dengan format Microsoft Word.

4. Redaksi berhak mengedit tata bahasa dan ejaan naskah yang dimuat tanpa mengurangi atau mengubah maksud tulisan.

\section{Ketentuan Sistematika Penulisan:}

\section{Artikel berupa hasil penelitian:}

\section{Judul}

Ditulis singkat dan padat (max 12 kata)

\section{Nama Penulis}

Nama penulis ditulis tanpa gelar, asal dan alamat lembaga, serta alamat email. (Khusus untuk artikel yang ditulis tim, hanya dicantumkan alamat email penulis utama).

\section{Abstrak}

Abstrak ditulis dalam Bahasa Inggris dan Bahasa Indonesia. Abstrak memuat uraian mengenai tujuan penelitian, metode yang digunakan, dan hasil penelitian. Abstrak ditulis secara ringkas, padat dan ditulis dalam satu alinea (maksimal 150 kata).

\section{Kata Kunci}

Kata kunci berisi ide-ide atau konsep dasar yang mewakili bidang yang diteliti. Kata kunci maksimal 5 kata.

\section{Pendahuluan}

Bagian ini berisi tentang latar belakang penelitian, permasalahan penelitian atau tujuan penelitian, dan rangkuman kajian teori yang berkaitan dengan masalah yang diteliti.

\section{Metode}

Bagian ini memuat rancangan atau desain penelitian yang dilakukan. Pada bagian ini paling tidak memuat tentang jenis penelitian, subjek/objek penelitian, teknik/instrumen pengumpulan data dan analisis data.

\section{Hasil dan Pembahasan}

Bagian ini memuat hasil analisis data, pengujian instrumen dan hipotesis (jika ada), jawaban pertanyaan penelitian, temuan-temuan dan interpretasi temuan-temuan.

\section{Simpulan}

Menyajikan simpulan hasil penelitian dan jika diperlukan dapat ditambahkan implikasi, keterbatasan dan saran

\section{Daftar Pustaka}

Memuat sumber-sumber yang diacu di dalam penulisan artikel, hanya sumber-sumber yang digunakan yang dimuat dalam daftar pustaka.

2. Artikel berupa hasil pemikiran, analisis ilmiah, dan kajian teori:

Judul

Ditulis singkat dan padat (maksimal 12 kata). 


\section{Nama Penulis}

Nama penulis ditulis tanpa gelar, asal dan alamat lembaga, serta alamat email. (Khusus untuk artikel yang ditulis tim, hanya dicantumkan alamat email penulis utama).

\section{Abstrak}

Abstrak ditulis dalam Bahasa Inggris dan Bahasa Indonesia. Abstrak memuat ringkasan artikel yang mencerminkan gambaran umum masalah yang dibahas dalam artikel dan halhal yang sedang dikritisi dan ditulis dalam satu alinea (maksimal 150 kata).

\section{Kata Kunci}

Kata kunci berisi ide-ide atau konsep dasar yang mewakili bidang yang ditulis. Kata kunci maksimal 5 kata.

\section{Pendahuluan}

Menguraikan pentingnya permasalahan yang dibahas beserta latar belakangnya, mengemukakan permasalahan yang dibahas dan tujuan pembahasan.

\section{Pembahasan}

Bagian ini berisi kajian terhadap permasalahan yang sedang dibahas. Isinya dapat meliputi analisis, argumentasi teoretik mengenai permasalahan yang dibahas. Subbab yang ditulis dapat menyesuaikan dengan permasalahan yang sedang dibahas.

\section{Simpulan}

Berisi simpulan penulis terhadap masalah yang dibahas, termasuk saran-saran atau sikap alternatif jika ada.

\section{Daftar Pustaka}

Memuat sumber-sumber yang diacu di dalam penulisan artikel, hanya sumber-sumber yang digunakan yang dimuat dalam daftar pustaka.

\section{Ketentuan Format Penulisan:}

1. Artikel dapat disajikan dalam bahasa Inggris atau bahasa Indonesia.

2. Artikel dikirim sebanyak satu eksemplar disertai soft copy.

3. Artikel yang tidak dimuat tidak dikembalikan.

4. Panjang tulisan antara $10-20$ halaman dan ditulis dalam kertas ukuran A4 dengan spasi 1,5 .

5. Jenis huruf yang digunakan: Times New Roman ukuran 12

6. Margin atas, bawah dan samping 1 inci.

7. Setiap tabel atau gambar diberi nomor urut, judul, yang sesuai dengan isi tabel dan gambar, dan sumber kutipan (jika ada). Sumber kutipan ditulis di bawah gambar atau tabel. Judul tabel ditulis di atas tabel dan judul gambar ditulis di bawah gambar.

8. Semua halaman termasuk tabel, lampiran dan daftar pustaka diberi nomor urut halaman.

9. Sumber kutipan dalam teks ditulis di antara kurung buka dan kurung tutup yang menyebutkan nama akhir penulis, tahun, dan nomor halaman jika dipandang perlu. Contoh:

- Apabila kutipan berasal dari satu sumber: (Kuncoro, 2009), (Kuncoro, 2009: 131), (Ebel \& Frisbie, 1991: 86), (Case, et.al., 2012) atau (Sugiyono, dkk., 2006)

- Apabila kutipan berasal dari dua sumber dengan penulis yang berbeda: (Cohen, 2009: 163; Nunnally \& Bernstein, 1994: 252)

14. Daftar pustaka ditulis alphabetis sesuai dengan nama akhir (tanpa gelar akademik), baik penulis asing maupun penulis Indonesia dengan contoh sebagai berikut: 


\section{Jurnal:}

Yelle, L.E. (1980) "Industrial Life Cycles and Learning Curves: Marketing and Production Interaction". Industrial Marketing Management, 9(4), 311-318.

Darmawan, I. (2006) "Pembangunan Manusia Sebagai Sarana Pemberdayaan Masyarakat Miskin". Jurnal Economia, 2(1), 1-11.

\section{Laporan Penelitian:}

Sumarno, dkk. (2012) "Implementasi Kebijakan Desentralisasi Pendidikan Dasar". Laporan Penelitian. Yogyakarta: LPPM UNY.

\section{Buku:}

Kuncoro, M. (2009) Metode Riset untuk Bisnis \& Ekonomi: Bagaimana Meneliti \& Menulis Tesis? (Edisi 3). Jakarta: Erlangga.

Ebel, R.L. \& Frisbie, D.A. (1991) Essential Of Educational Measurement (5 ${ }^{\text {th }}$ Edition). New Delhi: Prentice-Hall, Inc.

Krugman, P.R., et.al. (2012) International Economics: Theory \& Policy (9 ${ }^{\text {th }}$ Edition). Boston: Addison-Wesley.

Internet:

White, H. (2007) Problem-Based Learning in Introductory Science Across Disciplines. Diakses dari http://www.udel.edu/chem/white/finalrpt.html pada tanggal 6 Januari 2011. 